\title{
Is the 'Orientalist' past the future of Middle East studies?
}

\section{Pinar Bilgin}

To cite this article: Pinar Bilgin (2004) Is the 'Orientalist' past the future of Middle East studies?, Third World Quarterly, 25:2, 423-433, DOI: 10.1080/0143659042000174897

To link to this article: https://doi.org/10.1080/0143659042000174897

曲 Published online: 24 Jan 2007.

Submit your article to this journal $₫$

Џll Article views: 438

Citing articles: 6 View citing articles 5 


\title{
Is the 'Orientalist' past the future of Middle East studies?
}

\author{
PINAR BILGIN
}

\section{Ivory Towers on Sand: The Failure of Middle Eastern Studies in America Martin Kramer \\ Washington, DC: Washington Institute for Near East Policy: 2001, ISBN 0 944029493}

\section{American Orientalism: The United States and the Middle East Since 1945 Douglas Little}

Chapel Hill, NC: University of North Carolina Press, 2002, ISBN 0807827371

Localizing Knowledge in a Globalizing World: Recasting the Area Studies Debate Ali Mirsepassi, Amrita Basu \& Frederick Weaver (eds)

Syracuse, NY: Syracuse University Press, 2003 ISBN 0815629826

'Is there a future for Middle East studies?' was the title of Rashid Khalidi's presidential address to the annual convention of the Middle East Studies Association in $1994 .{ }^{1}$ Khalidi's own answer was that, in order for Middle East studies to have a future, scholars would need to reach beyond their own area of interest to other areas, reach out to the general public via teach-in and outreach activities as well as through the media, and communicate to the rest of their colleagues in the broader social science disciplines (such as political science and economics). Khalidi's was by no means the only response to this question. Characterising the current state of the field as a 'crisis', Jerrold Green argued that 'some intellectual stock-taking is required' and that when doing this 'the conceptual horse should be put in front of the areal [sic] cart so that scholarly investigation is hung on a stronger intellectual need than the mere fact that the region is interesting'. ${ }^{2}$ Robert Bates's suggestion echoed that of Green: area studies specialists should embrace the move towards a disciplinary-orientated view which would amount to scholars gaining new skills in the use of formal theory, statistical methods and mathematics, he argued. ${ }^{3}$ In Ivory Towers on Sand: the Failure of Middle Eastern Studies in America, Martin Kramer presents a critique of Middle East studies that is based less on disciplinary than on political grounds. It is time for Middle East specialists, he argues, to put their house in order and look critically at themselves and drop 'fashionable' theo-

Pinar Bilgin is in the Department of International Relations, Bilkent University, Bilkent, Ankara 06533, Turkey. 
ries - a legacy of Edward Said's Orientalism, ${ }^{4}$ Kramer thinks-in favour of straightforward policy-relevant work by adopting approaches that would 'explain and predict' change in the Middle East. This, the author maintains, could best be remedied by going back to their roots in Oriental studies ${ }^{5}$ to 'restore some continuity with the great tradition'. 6

Such debates are by no means unique to Middle East studies. On the contrary, these debates should be understood within the context of the end of the Cold War, which gave rise to questions regarding the relevance of area studies in an increasingly globalising world. ${ }^{7}$ The Social Science Research Council (SSRC) and the American Council of Learned Societies (ACLS) reacted by dissolving their joint area studies committees, which had administered funding for area studies since the 1950s. In the early 1990s sponsors too withdrew funds from area studies centres and drew up guidelines to promote thematic and interdisciplinary research more relevant to post-cold war concerns (such as post-communist transition and the effects of structural adjustment programmes).

What is distinctive about Middle East studies is the political character of the debate on the future of the field. Indeed, in Summer 2003, the issue of the future of Middle East studies was taken up by the US Congress, where critics voiced their conviction that Middle Eastern specialists were abusing government funds provided under Title VI of the National Defense Education Act (under which grants to area centres have been administered since 1958) and producing 'extreme and one-sided criticisms of American foreign policy'. ${ }^{8}$ These criticisms build upon Kramer's book, where the author takes issue with Middle East specialists on both disciplinary grounds (for failing to explain and predict changes in the Middle East) and political grounds (for failing to serve US policy needs and interests). Kramer's suggestion is that if the academy remains defiant, the government should step in and use the lever of financial support to initiate reform. After all, maintains Kramer, 'the last thing Middle Eastern studies have sought to do this last quarter-century has been to serve American foreign policy or private initiative'. 9 Therefore, argues the author, the government should make changes in Title VI, thereby making sure Middle East specialists become more sensitive to governmental needs and interests when producing research. Such criticism has meant that in the post-cold war era, Middle East specialists have had to defend themselves not only against their disciplinary colleagues in the broader field of political science, who considered area studies work to be theoretically and methodologically unsophisticated, but also against their more politically orientated critics, who sought to reshape Middle East studies.

Kramer's trenchant critique of the ways in which the Middle East has been studied and presented in US institutions of higher education in the postwar era, and his submission that Middle East studies should go back to its roots in Oriental studies, can be discussed with reference to a number of different contexts. First, there is the post-cold war context, which has given rise to debates on the relevance of area studies in an increasingly globalising world. The first section will address this dimension of Kramer's critique with reference to Mirsepassi et al's edited volume, Localizing Knowledge in a Globalising World, which takes up the broader issue of the future of area studies. Second, Kramer's argument could be interpreted with reference to the legacy of Said's Orientalism 
in Middle East studies. In the next section Kramer's preferred future for Middle East studies will be discussed with reference to Douglas Little's study, American Orientalism, which looks at the practical impact of the Orientalist outlook and shows how it has shaped and limited US policy making in the Middle East, thereby causing otherwise well intended policies to have negative consequences. The essay will conclude by locating Kramer's work within broader debates on the relationship between scholarship and policy making.

\section{The relevance debate}

The debate between area studies and the social sciences is not new. Long before 'globalisation' replaced the 'Cold War' as the prism through which world politics is viewed, thereby giving rise to calls for shifting our attention to 'universal' knowledge to the neglect of contextual knowledge, methodological and epistemological differences kept area studies specialists and disciplinary generalists apart. It was widely accepted that disciplinary generalists made universalistic claims that came out of the Western experience, while area studies specialists made particularistic claims about the non-industrialised world. Constitutive of this disciplinary division of labour was the assumption that area studies merely served as a pool of data for testing theories that were developed based on the Western experience. This disciplinary division of labour was also constitutive of the hierarchy between area studies specialists and disciplinary generalists. It was based on this divide that students of world politics were led to think 'that the only worthwhile way of engaging with the politics and history of world regions is to the extent that they can be made to appear as particular instances of the universal stories told in and about the West'. ${ }^{10}$ This division of labour and hierarchy between area studies and the disciplines has impoverished both in that area specialists often rejected universal categories emphasising the uniqueness of regional dynamics, thus leaving untouched distinctions between local and global and 'the way in which this distinction awards to some phenomena a universal essence, rationality, and energy but renders others merely static, reactive, or "cultural", 11

Yet, as Ian Lustick reminds us, such distinctions should no longer be seen as keeping area studies specialists and disciplinary generalists apart, for:

we are in a better philosophical position than we were in the past to evaluate positions taken in the debate over area studies and the other disciplines of political science. Any position which insists on the availability of theory-free facts, whether facts produced to test theories or facts produced as reports of objective reality, should be equally suspect. ${ }^{12}$

Notwithstanding such sophistication in epistemologies, 'the crisis of area studies' is still presented as a clash between (purportedly) 'theory-free' area studies (the relevance of which is considered to have declined), and 'scientific' approaches to world politics (which are thought to have remained relevant thanks to their ability to explain and predict world politics by adopting rational choice approaches and game theory). ${ }^{13}$

Kramer takes his cue from the disciplinary generalists' critique of area studies 
when he criticises Middle East specialists for their failure to 'explain and predict'. ${ }^{14}$ What is not clear is whether Kramer is critical of Middle East scholars for failing to adopt those 'scientific' approaches that embrace rational choice theory to explain and predict, or whether he is criticising them for their failure to do what interpretive methods allow, that is, to understand Middle East politics. ${ }^{15}$ Judging by his preference for Middle East studies to return to its Orientalist roots, Kramer does not seem to be in favour of Middle East scholars embracing the move toward a disciplinary-orientated view of area studies. Kramer's use of the language of disciplinary generalists when criticising Middle East studies seems based on political expediency at best.

Kramer justifiably points out that it was Middle East specialists who sought to make a break with their roots in Oriental studies and adopted a more 'scientific' approach to regional politics. In this sense it may seem fair to criticise them for failing by the standards that they set. Yet those who engineered the transition from Oriental studies to Middle East studies in the 1950s did not embark upon a quest for predictive theory. Indeed 'until 1960 no Center of Middle Eastern Studies at any American university was headed by a social scientist or contained a majority of social scientists on its staff' ${ }^{16}$ A survey of the literature in 1967 found that, if one were to adopt a strict definition of political science 'that would insist on fully explicit concepts and theories, hypothesis testing, and social scientific experimentation', very few studies on the Middle East would qualify. ${ }^{17} \mathrm{~A}$ decade later another survey reported a similar finding: single-case study methodologies made up $84.3 \%$ of the articles published. Few $(9.3 \%)$ were comparative approaches. Still fewer adopted statistical $(5 \%)$ and quasi-experimental $(1.4 \%)$ methods. ${ }^{18}$ This is indeed the reason why Middle East specialists (like other area specialists) have been criticised for '[lagging] behind others in terms of their knowledge of statistics, their commitment to theory, and their familiarity with mathematical approaches to the study of politics'. ${ }^{19}$

In the post-cold war environment, where the value of knowledge about 'exotic' parts of the world has declined, disciplinary generalists' criticisms of area specialists have been taken up by the critics to justify the decision to cut budgets for area studies centres. ${ }^{20}$ Yet what the critics have failed to note is that donors such as the Ford Foundation have given area studies specialists the opportunity to restructure their studies and collaborate with other disciplines. ${ }^{21}$ Mirsepassi et al's study is particularly interesting for being a product of the process of post-cold war rejuvenation in area studies and a good example of how scholars of area studies background can produce work that seeks to revise not only area studies but also the disciplines.

As Mirsepassi et al note in their introduction, the volume was made possible by two separate grants from the Ford Foundation extended under the 'Crossing Borders' programme set up in the early 1990s in the attempt to foster closer links between area studies and the disciplines. The editors maintain that the globalisation of world politics, the rise of rational choice theory in the social sciences and the increasing popularity of cultural and postcolonial studies (which focus on the local and challenge area studies' conception of area as based on colonial notions of what constitutes a 'region') $)^{22}$ has not diminished but increased the need for 
area-based knowledge. For, 'it is precisely the relationship between global processes and area-based knowledge that opens up new perspectives on globalising societies, nations and cultures'. ${ }^{23}$

The contributors to the volume all underline the continuing need for areabased knowledge in a globalising world. Escobar's, Haugerud's (especially), Basu's and Abu-Lughod's chapters emphasise links between the local and global and the need to study both in order to understand the mutually constitutive relationship between the two. Some take a step further, calling for revamping both area studies and the disciplines (Ludden) or collapsing the disciplines into area studies (Mitchell). Others (such as Dirlik and Ahmad) present critiques of the literature on globalisation from a perspective informed by area-based knowledge. What distinguishes this study is the way in which the continuing significance of area-based knowledge is highlighted with reference to different geographies (such as the Middle East, 'Neo York' and Egypt) and disciplines (American studies, linguistics, Middle East studies, African studies, anthropology). Yet none of the contributors considers going back to the Orientalist roots as the way out of the crisis in Middle East studies. On the contrary, they emphasise how 'the Orientalist enterprise' has produced its 'most ardent critics $^{24}$ and how this transformed area studies in the late 1960s and early 1970s.

Particularly telling is the transformation of Asian studies. Asian specialists were radicalised during the Vietnam war and successfully challenged official US representations of Vietnam and the war, thereby playing 'important roles in making US academia less parochial and US policymakers more accountable'. ${ }^{25}$ A similar process of radicalisation began in Middle East studies in the aftermath of the 1967 war. However, it was not until the publication of Orientalism that Middle East studies began to transform along parallel lines. Such 'epistemological backwardness' has led one scholar to label Middle East studies as the 'Rip Van Winkle of the regional studies scene'. ${ }^{26}$

Orientalism's impact on Middle East studies cannot be denied. As Earl Sullivan and Jacqueline Ismael have maintained, 'much of what has appeared in the field since 1978 has been in reaction to Said's study'. ${ }^{27}$ In Kramer's view, it was during this period that Middle East studies ceased to be relevant to US interests. This was not only because Middle East specialists adopted 'postmodernist' approaches that led them to stop seeking to produce 'objective' research and 'spell out their own political commitments as a preface to anything they wrote or did', ${ }^{28}$ maintains Kramer, but also because they 'alienated' policy makers by producing work critical of US policies. This negative view of the impact Orientalism has made on Middle East studies contrasts with Mirsepassi et al's positive view explained above. It also contrasts with Douglas Little's account of US foreign policy towards the Middle East.

\section{The legacy of Said's Orientalism}

In American Orientalism: The United States and the Middle East since 1945, Little presents a critical account of US policies towards the Middle East between 1945 and 2001. What renders Little's approach different from many other accounts of US Middle East policies is in the way in which he presents US 
successes and failures as shaped by the persistence of 'American orientalism', defined as 'a tendency to underestimate the peoples of the region and to overestimate America's ability to make a bad situation better' ${ }^{29}$ The practical impact of 'American orientalism', according to Little, has been demonstrated in successive US administrations' dismissive attitudes towards the nationalist aspirations of Arabs and Iranians as 'manifestations of oil-inspired economic arrogance, anti-Semitic rabble-rousing, or oriental affinity for revolutionary despotism of the sort made infamous by the Kremlin'. ${ }^{30}$ The author develops this argument throughout by examining US policies towards the Middle East from many angles. They include the significance of oil, US encouragement of modernisation, experiences of limited wars, national security doctrines adopted as part of the policy of containment, the special relationship with Israel, Arab nationalism, and the Arab-Israeli peace process.

If it was not for 'American orientalism', which shaped and limited US policies towards the Middle East, submits Little, US policy makers might have shown 'greater sympathy for the devil of revolutionary nationalism after 1945' which, in turn, 'might have helped to prevent America's hellish confrontation with Osama bin Laden and Islamic extremism early in the new millennium'. ${ }^{31}$ What is significant to note here is that it was not merely an Orientalist outlook but also the ethnocentric character of US security thinking that caused policy failures in the Middle East (and elsewhere). ${ }^{32}$ What is meant by ethnocentrism here is 'making false assumptions about others' ways based on our own limited experience'. ${ }^{33}$ The ethnocentric character of US security thinking manifested itself in US strategists' failure to see how the policy priorities and security thinking of the Soviets (as well as the Middle Eastern actors) differed from theirs.

To go back to Little's argument about American Orientalism, the contrast between Kramer's and Little's understandings of what Orientalism is, and its impact on US thinking about and policies toward the Middle East, are interesting. From Kramer's perspective Orientalism is a 'great tradition' which was discredited by Said's writings. Said is critical of the Orientalist tradition, in Kramer's view, because he considers it a 'supremacist ideology of difference, articulated in the West to justify its dominion over the East'. ${ }^{34}$ This clearly is a part of Said's critique. Yet there is more to Said's definition of Orientalism than that. Said understands Orientalism as 'a style of thought based upon an ontological and epistemological distinction made between "the Orient" and (most of the time) "the Occident", ${ }^{35}$ The Orientalist discourse does not merely represent the 'Orient' but also lays down the rules that enable one to 'write, speak, listen and act meaningfully'. ${ }^{36}$ Defined as such, 'prejudicial', or 'supremacist' thinking is merely the tip of the Orientalist iceberg. Besides, one need not be prejudicial for his/her thinking and action to be influenced by the Orientalist outlook. As Little has shown, successive US governments were victims of the Orientalist outlook that not only limited how they were able to think about the Middle East but also established a hierarchical distinction between the Middle East and the West, thereby resulting in an underestimation of Middle Eastern actors and overestimation of what the US was capable of. Not even State Department 'Arabists', who were known (and criticised within the US 
establishment) for their sympathy for the Arab world, ${ }^{37}$ could escape the limits imposed by the Orientalist outlook.

Kramer's narrow understanding of Orientalism also betrays a narrow view of theory and the purposes it serves. For Kramer, there are two kinds of theory: those that 'explain and predict' and those 'fashionable' theories that obscure (which correspond to Robert Cox's problem-solving theory/critical theory distinction).$^{38}$ Kramer is clearly in favour of more of the former; he considers Said's influence on Middle East studies as unfortunate for having encouraged the latter. When making a case for Middle East studies to go back to its Orientalist roots, Kramer emphasises the need for approaches that would 'explain and predict'. In other words, he expects Middle Eastern specialists to adopt problem-solving theories that take the existing social order as given and merely seek to uphold stability. Kramer's understanding of theory as an explanatory and problem-solving tool also fits with his concern that Middle East specialists relate to the policy agenda. He expects academics to talk to the practitioners and produce policy-relevant work. However, since Kramer rejects the relevance of 'critical' approaches to the study of world politics, he also fails to note how theories are constitutive of the reality they purport to explain —an issue central to Said's thinking. For theories do not just explain but are constitutive of the 'reality' they respond to. They help organise knowledge, which, in turn, privileges certain practices while marginalising others, thereby helping to shape the world in line with their tenets. ${ }^{39}$ From Said's critical perspective, the role of the scholar is to point to the constitutive role theories play as opposed to contributing to the maintenance of the status quo (by assuming the theory/practice relationship to be neutral and the role of theory to be to explain the world for those who try to solve its problems). ${ }^{40}$ The latter job is what the Orientalist tradition did best by providing knowledge for the imperial power. ${ }^{41}$ Viewed like this, Kramer's preferred vision for Middle East studies would involve restoring the links between scholarship and policy making established during the age of imperialism-those links that Said's Orientalism sought to shed light upon. ${ }^{42}$

\section{The relationship between scholarship and policy making}

Kramer points to the 'relevance gap that has opened up between academics and policy-makers, and the alienation that besets both sides ${ }^{\prime 43}$ as the factor that motivated him to write Ivory Towers on Sand. In his opinion Middle East specialists owe the US government some contribution to policy making not only because it was the government that provided funds through Title VI but also because this was what Middle East specialists promised when they initially applied for government funding to set up Middle East centres in the mid-1940s. The broader point being that Middle East specialists who refuse to engage with policy-relevant work have betrayed not only the government but also the founding fathers of Middle East studies. At least three points need elaboration.

First, that Middle East specialists played a critical role in getting the US government interested in Middle East centres should not be interpreted to underestimate the role cold war concerns played in the process. After all, Middle East scholars had tried before (in the interwar era) to set up area studies centres 
but with little success. At the time, scholars sought to emphasise how 'studies of ancient language and history can serve to avoid conflict by correcting the distorted perspective of a narrow nationalism, and promoting international sympathy and understanding between East and the West'. ${ }^{44}$ Considering the academic and political environment of the time, characterised by the prevalence of the 'Idealist' approach to International Relations (inspired by Wilsonian idealism), Middle East specialists' argument was clearly in tune with the rest of US academe as well as the US foreign policy establishment. Then, when Middle East specialists tried to make a case for Middle East centres in the aftermath of World War II they were merely following in the footsteps of their predecessors who also sought to develop the field by invoking its relevance to US interests.

Second, those scholars who lobbied for government funding were not strangers to affairs of the state. Many had served the US war effort during World War II. The links established during the war were maintained. ${ }^{45}$ Once Middle East centres were set up, State Department representatives sat on the boards of selection committees when deciding which projects to fund-a practice not common to all area studies. Clearly, the government was not uninterested in Middle East studies as Kramer seems to suggest. There were organic links between government anxieties and interests on the one hand, and academic anxieties and interests on the other; both sides needed and used each other. ${ }^{46}$

Third, policy-relevance was the keyword of the early years of the Cold War for both area specialists and disciplinary generalists alike. As Steven Bernstein et al have noted, disciplinary generalists' 'commitment to social science flowed from an even deeper commitment- to use disciplined methodologies to generate knowledge that would help prevent the horrors of war and fascism and improve the world around them' ${ }^{47}$ As time progressed, this vision was lost among the disciplinary generalists, for some of whom 'scientific means' has become an end in itself. On the other hand, 'those who [did] study policy problems frequently [did] so in isolation from those working seriously with theory' ${ }^{48}$ A similar split occurred among area specialists for reasons that had less to do with the impact of Orientalism than with broader trends in international studies. In this sense, what Kramer presents as unique to Middle East studies was also experienced by the disciplines in that, over the years, links between university-based scholars and policy makers weakened while another group (mostly located in think-tanks) produced policy-relevant (supposedly) theory-free work.

Kramer's ideal Middle East specialist is a modern day Machiavelli who produces knowledge to inform policy making. Critics of such a relationship have for long maintained that governments do not merely seek information when they consult scholars; they also seek the 'legitimation of government policy through the reproduction and dissemination of the canons of official orthodoxy' ${ }^{49}$ Besides, they argue, scholars should resist the 'siren song of policy relevance' and make use of the privilege and marginal advantage created by their detachment rather than engaging in immediate policy issues. ${ }^{50}$

It is possible to explain away these opposing views by referring to the gap between theory and practice and stating that scholars and policy makers each have a false image of what the other does. ${ }^{51}$ Such explanations rest upon the assumption that theory and practice could be thought of as totally separate 
activities. However, the choice is not necessarily one of choosing to inform policy making or not; there are deeper issues involved. Setting the scholar's dilemma as one of deciding whether to inform policy making or to isolate $\mathrm{him} /$ herself in the ivory tower, rests on a very narrow conception of theory as well as practice. For theory is not limited to abstractions about world politics. Policy makers themselves adopt one theory or another, although they may not be aware of or open about it. It is the task of the scholar to reflect upon and warn policy makers of their unquestioned assumptions. Kramer's view of practice is also narrow because he understands practice as government policy making. However, there exist other actors (non-governmental actors, students or scholars who teach and/or engage in activism of one sort or another) whose practices theory seeks to inform. Even those scholars who do not address the policy agenda could foster change by questioning existing assumptions and challenging common sense. This is what Said sought to do in his lifetime. ${ }^{52}$

One final point relates to Kramer's submission that Middle East studies has 'failed' its major funder, the US government, and that the remedy would be found by going back to its roots in Oriental studies to re-establish links between Middle East scholarship and policy making. Although Middle East studies could be considered to have 'failed' on the surface by failing to produce 'problemsolving theory' and thus alienating US policy makers, it could be considered to have 'succeeded' at a much deeper level. For Middle East studies has come to shape the thinking of Middle East specialists around the world; shaping knowledge is the ultimate sign of power. Thanks to Middle East centres based in US universities, an American prevalence exists in Middle East studies: the thinking patterns and modes of representation used by Middle East specialists around the world are shaped by this 'American invention'. ${ }^{53}$ The phenomenon of the 'indigenisation' of Middle East studies in the USA (poked fun at by the critics who say that the Middle East Studies Association has changed 'from an American organization interested in the Middle East to a Middle Eastern one that happens to meet in the United States' $)^{54}$ could be viewed as a sign of 'success' for Middle East studies. Whatever the immediate policy implications of research conducted in area studies centres might have been, at a deeper level, they have been highly influential in laying down the rules that enable one to "write, speak, listen and act meaningfully'55 - that is, through inside out. Such a development would have been unfathomable within the limits imposed by the Oriental studies tradition that rested on the Orient/Occident divide and did not allow the 'Middle East' to represent itself..$^{56}$ Those who make a case for Middle East studies going back to its Orientalist roots would do well to rethink the deeper impact this academic field has made over the years.

\section{Notes}

The author would like to thank Adam David Morton, Bilge Criss, Tore Fougner and Umit Cizre for comments.

1 Rashid Khalidi, 'Is there a future for Middle East studies?', Middle East Studies Association Bulletin, July 1995, at http://w3fp.arizona.edu/mesasoc/Bulletin/khalidi.htm, accessed 25 October 2000.

2 Jerrold D Green, 'The politics of Middle East politics', PS: Political Science and Politics, 27 (3), 1994, p 517. 
3 Robert Bates, 'Area studies and the discipline: a useful controversy?', PS, 30 (2), 1997, p 169.

Edward W Said, Orientalism, New York: Vintage, 1978.

Here the term Oriental studies is used to refer to the early tradition.

Kramer, Ivory Towers on Sand, p 123.

7 See, for example, Neil L Waters (ed), Beyond the Area Studies Wars: Toward a New International Studies, Hanover, NH: University Press of New England, 2000; Mark Tessler, Jody Nachtweu \& Anne Banda (eds), Area Studies and Social Science: Strategies for Understanding Middle East Politics, Bloomington, IN: Indiana University Press, 1999.

8 Stanley Kurtz, 'Studying Title VI: criticisms of Middle East studies gets a congressional hearing', National Review Online, at http://www.nationalreview.com/script/printpage.asp?ref =/kurtz/kurtz061603.asp, accessed 12 September 2003.

9 Kramer, Ivory Towers on Sand, p 126.

10 Timothy Mitchell, 'Deterritorialization and the crisis of modern science', in Mirsepassi et al, Localizing Knowledge in a Globalizing World, p 167.

11 Ibid, p 169. For example, the literature on 'failed states' rests on assumptions about "stateness" against which any given state should be measured as having succeeded or failed'. Presenting the experiences of developing states as 'deviations' from the norm not only reinforces commonly held assumptions about 'ideal' statehood but also inhibits reflection on the 'broader and more prevalent crises in the capacities and legitimacy of modern states'. See Jennifer Milliken \& Keith Krause, 'State failure, state collapse, and state reconstruction: concepts, lessons and strategies', Development and Change, 33 (5), 2002, pp 753-755.

12 Ian S Lustick, 'The disciplines of political science: studying the culture of rational choice as a case in point', PS, 30 (2), 1997, p 176. See also David Ludden, 'Why area studies?', in Mirsepassi et al, Localizing Knowledge in a Globalizing World, pp 131-136.

13 For a critique of the 'physics envy' in international studies, see John Lewis Gaddis, 'History, science, and the study of international relations', in Ngaire Woods (ed), Explaining International Relations Since 1945, Oxford: Oxford University Press, 1996, pp 32-48; and Steven Bernstein, Richard Ned Lebow, Janice Gross Stein \& Steven Weber, 'God gave physics the easy problems: adapting social sciences to an unpredictable world', European Journal of International Relations, 6 (1), 2000, pp 43-76. On the record of rational choice theory in the study of world politics, see Bruce Bruno de Mesquita, 'The benefits of a social-scientific approach to studying international affairs', in Woods, Explaining International Relations Since 1945, pp 49-76.

14 Kramer, Ivory Towers on Sand, p 16.

15 On the differences between explaining and understanding as distinct approaches to international studies, see Martin Hollis \& Steve Smith, Explaining and Understanding International Relations, Oxford: Clarendon Press, 1990. See also Alexander Wendt, 'On constitution and causation in International Relations', Review of International Studies, 24 (special issue), 1998, pp 101-117.

16 Manfred Halpern, 'Middle Eastern studies: a review of the state of the field with a few examples', World Politics, 15 (1), 1962, p 110.

17 I William Zartman, 'Political science', in Leonard Binder (ed), The Study of the Middle East: Research and Scholarship in the Humanities and the Social Sciences, New York: John Wiley, 1976, p 267.

18 Rex Brynen, 'The state of the art in Middle Eastern studies: a research note and the American empire', Arab Studies Quarterly, 4 (4), 1986, p 409.

19 Robert H Bates, 'Letter from the president: area studies and the discipline', APSA-CP Newsletter of the APSA Organized Section in Comparative Politics, 7 (1), 1996, p 1. Given the current prevalence of rational choice approaches in political science, the relevance of such criticisms remains.

20 Kramer, Ivory Towers on Sand, pp 120-130.

21 Philip S Khoury, 'Current developments and future directions in Middle Eastern studies', Frontiers, 6, 2000, at http://www.frontiers.com, accessed 10 September 2003.

22 See Rashid I Khalidi, 'The Middle East as an area in an era of globalisation', in Mirsepassi et al, Localising Knowledge in a Globalising World, pp 171-190 for a response to this challenge within the Middle Eastern context.

23 Mirsepassi et al, 'Introduction', in Localising Knowledge in a Globalising World, p 13.

24 Ibid, p 4.

25 Ibid.

26 Judith E Tucker, 'Middle East studies in the United States: the coming decade', in Hisham Sharabi (ed), The Next Arab Decade: Alternative Futures, Boulder, CO: Westview Press, 1988, pp 312-313.

27 Earl L Sullivan \& Jacqueline S Ismael, 'Introduction: critical perspectives on Arab studies', in Sullivan \& Ismael (eds), The Contemporary Study of the Arab World, Alberta: University of Alberta Press, 1991, $\mathrm{p} 2$.

28 Kramer, Ivory Towers on Sand, p 39.

29 Little, American Orientalism, p 314. 
$30 \quad$ Ibid, p 309.

31 Ibid, p 317.

32 On ethnocentrism in security thinking, see Ken Booth, Strategy and Ethnocentrism, New York: Holmes \& Meier, 1979.

33 Ken Barger, 'Ethnocentrism', available at http://www.iupui.edu/nanthkb/ethnocen.htm, accessed 17 September 2003.

34 Kramer, Ivory Towers on Sand, p 28.

35 Said, Orientalism, p 2.

36 John Agnew \& Stuart Corbridge, Mastering Space: Hegemony, Territory and International Political Economy, London: Routledge, 1995, p 45.

37 Robert Kaplan, The Arabists: The Romance of an American Elite, New York: Free Press, 1993.

38 On the distinction between 'problem-solving' and 'critical' theories, see Robert W Cox, 'Social forces, states and world orders', Millennium: Journal of International Studies, 10 (2), 1981, pp 126-158.

39 On the distinction between 'descriptive' and 'constitutive' theory, see Steve Smith, 'The Self-images of a discipline: a genealogy of international relations theory', in Ken Booth \& Steve Smith (eds), International Relations Theory Today, Oxford: Polity Press, 1995, pp 1-37.

40 See Edward W Said, Representations of the Intellectual: The 1993 Reith Lectures, London: Vintage, 1994.

41 Kramer also underestimates the role imperial interests played in the making of Oriental studies. The author mentions 'the experience of Crusade, Renaissance and Enlightenment' (p 5) yet leaves out colonialism and imperialism as factors that have shaped the study of the Orient.

42 See also Edward W Said, Covering Islam: How the Media and the Experts determine how We see the Rest of the World, London: Vintage, 1997; and Said, Power, Politics and Culture: Interviews with Edward W Said, ed Gauri Viswanathan, New York: Vintage, 2001.

43 Kramer, Ivory Towers on Sand, p 2.

44 Peter Johnson \& Judith Tucker, 'Middle East studies network in the United States', MERIP Reports, 38, 1975, p 4.

45 Richard D Lambert, 'DoD, social science, and international studies', ANNALS of the AAPSS, 502, 1989, p 95.

46 Georgetown University, which had missed the 'boom years' of US government funding, solicited the Gulf governments to set up its Center for Contemporary Arab Studies.

47 Bernstein et al, 'God gave physics', p 43.

48 Ibid, pp 43-4.

49 Irene L Gendzier, 'Following the flag', Middle East Report, October-December 1997, p 10.

50 Chris Hill, 'Academic international relations: the siren song of policy relevance', in Christopher Hill \& Pamela Beshoff (eds), Two Worlds of International Relations: Academics, Practitioners and the Trade in Ideas, London: Routledge, 1994, pp 3-25.

51 Alexander George, Bridging the Gap: Theory and Practice in Foreign Policy, Washington, DC: US Institute of Peace Press, 1993.

52 See, for example, Naseer Aruri \& Muhammad A Shuraydi (eds), Revising Culture, Reinventing Peace: The Influence of Edward W Said, New York: Olive Branch Press, 2001; and Rashid Khalidi, 'Edward W Said and the American public sphere: speaking truth to power', Boundary 2, 25 (2), 1998, pp 161-177.

53 Kramer, Ivory Towers on Sand, p 5.

54 Norvell B De Atkine \& Daniel Pipes, 'Middle Eastern studies: what went wrong?', Academic Questions, 9 (1), 1995, p 70.

55 Agnew \& Corbridge, Mastering Space, p 46. For a discussion on the theoretical and practical impact of area studies on current approaches to 'failed states', see Pinar Bilgin \& Adam David Morton, 'Historicising representations of "failed states": beyond the cold war annexation of the social sciences?', Third World Quarterly, 23 (1), 2002, pp 55-80.

56 Notwithstanding criticisms that the Middle East is still being represented and is not allowed to represent itself, the level of introspection and change in Middle East studies cannot be denied. 